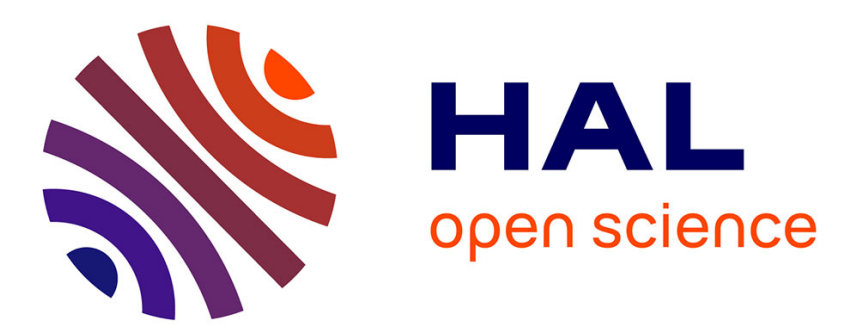

\title{
Sperm utilization in honeybees (Apis mellifera scutellata and A. m. capensis) in South Africa
}

Michael Holmes, Michael Allsopp, Lee-Ann Noach-Pienaar, Theresa Wossler, Benjamin Oldroyd, Madeleine Beekman

\section{- To cite this version:}

Michael Holmes, Michael Allsopp, Lee-Ann Noach-Pienaar, Theresa Wossler, Benjamin Oldroyd, et al. Sperm utilization in honeybees (Apis mellifera scutellata and A. m. capensis) in South Africa. Apidologie, 2011, 42 (1), pp.23-28. 10.1051/apido/2010031 . hal-01003563

\section{HAL Id: hal-01003563 https://hal.science/hal-01003563}

Submitted on 1 Jan 2011

HAL is a multi-disciplinary open access archive for the deposit and dissemination of scientific research documents, whether they are published or not. The documents may come from teaching and research institutions in France or abroad, or from public or private research centers.
L'archive ouverte pluridisciplinaire HAL, est destinée au dépôt et à la diffusion de documents scientifiques de niveau recherche, publiés ou non, émanant des établissements d'enseignement et de recherche français ou étrangers, des laboratoires publics ou privés. 


\title{
Sperm utilization in honeybees (Apis mellifera scutellata and $A$. m. capensis) in South Africa*
}

\author{
Michael J. Holmes ${ }^{1}$, Michael H. AllsopP ${ }^{2}$, Lee-Ann NoAch-PIENAAR ${ }^{3}$, \\ Theresa C. WossLer ${ }^{3}$, Benjamin P. OLdROYD ${ }^{1}$, Madeleine BEEKMAN $^{1}$ \\ ${ }^{1}$ Behaviour and Genetics of Social Insects Lab, School of Biological Sciences A12, University of Sydney, NSW \\ 2006, Australia \\ ${ }^{2}$ Honeybee Research Section, ARC-Plant Protection Research Institute, Private Bag X5017, Stellenbosch 7599, \\ South Africa \\ ${ }^{3}$ Department of Botany and Zoology, University of Stellenbosch, Private Bag X1, Matieland 7602, South Africa
}

Received 12 August 2009 - Revised 4 January 2010 - Accepted 3 February 2010

\begin{abstract}
We artificially inseminated queens of Apis mellifera scutellata and A. $m$. capensis with equal numbers of drones of both subspecies to determine the effects of sperm genotype on rates of sperm utilization. Contrary to a previous study we did not find a consistent overrepresentation of workers sired by A. m. scutellata males in the first four months after insemination. Interestingly, our study does suggest that there is a significant interaction between drone and queen genotype in both subspecies, with queens of each subspecies producing more workers sired by drones of the same subspecies.
\end{abstract}

Apis mellifera scutellata / Apis mellifera capensis / sperm competition / Africanization / hybrid zone

\section{INTRODUCTION}

South Africa is home to two subspecies of honeybee, the African bee Apis mellifera scutellata (hereafter scutellata), and the Cape honeybee, A. m. capensis (hereafter capensis). Capensis is confined to the southern part of the Western and Eastern Cape, whereas scutellata is found throughout the rest of South Africa and countries to its north (Hepburn and Radloff, 1998). The two subspecies interact within a hybrid zone, producing (when queens mate with males of both subspecies) mixed colonies comprising both pure and hybrid workers (reviewed in Beekman et al., 2008). Capensis is unique in that it is the only subspecies or species of Apis in which workers are capable of thelytokous parthenogenesis, the production of diploid offspring with-

Corresponding author: M. Beekman, mbeekman@bio.usyd.edu.au

* Manuscript editor: Marina Meixner out mating (Onions, 1912; Verma and Ruttner, 1983). This ability allows it to become a lethal social parasite of scutellata colonies, as capensis workers can enter a scutellata colony, activate their ovaries and lay eggs which in turn develop into reproductive adults (Martin et al., 2002; Beekman et al., 2008). Reproductive workers do not participate in normal hive duties, causing colony collapse if they become too numerous (Martin et al., 2002).

Scutellata was introduced into Brazil in 1956. Descendents of this introduction, known as the Africanized honeybee (AHB), have subsequently spread throughout the tropical and subtropical regions of the Americas (Spivak et al., 1991). The invasiveness of AHB in the Americas led to concerns that the scutellata population from which AHB descended would eventually overrun the capensis population (Anderson, 1980). Conversely, anthropogenic introductions of capensis into scutellata's native range have led to the death of 
thousands of scutellata colonies due to capensis parasitism (Allsopp, 1992). Yet, despite the competitive adaptations of both subspecies the hybrid zone separating capensis and scutellata appears to be stable (Hepburn and Crewe, 1991). It has been postulated that south of the zone, capensis's social parasitism gives it a selective advantage, while in the north, scutellata has an advantage due to its high reproductive rate (Beekman et al., 2008).

In this study, we examined whether scutellata patrilines are over-represented in the offspring of both capensis and scutellata queens inseminated with equal numbers of drones of both subspecies. It was recently suggested that sperm of AHB males has an advantage over sperm from non-AHB males; when queens were artificially inseminated with sperm from both AHB and European drones, more workers were sired by AHB males compared with European males in months 2, 3 and 4 after inseminations (DeGrandi-Hoffman et al., 2003). If scutellata is able to out-compete capensis via sperm competition, then this may be one factor that gives scutellata a reproductive advantage in the northern part of the hybrid zone (Beekman et al., 2008).

\section{MATERIALS AND METHODS}

\subsection{Queen-rearing}

Capensis colonies used in this study were unselected colonies typical of those found around Stellenbosch, Western Cape $\left(33^{\circ} 56^{\prime} \mathrm{S}, 18^{\circ} 51^{\prime} \mathrm{E}\right)$. Scutellata colonies were obtained from Douglas, Northern Cape ( $\left.26^{\circ} 01^{\prime} \mathrm{S}, 29^{\circ} 22^{\prime} \mathrm{E}\right)$. Stellenbosch is well south of the hybrid zone whereas Douglas is well north of the zone within scutellata's native range (Hepburn and Crewe, 1991). To reduce the likelihood of social parasites destroying our experimental colonies, the scutellata colonies were moved to an apiary separate from the capensis colonies near Stellenbosch. Queens were reared in late September and early October 2008. Queencells were harvested from the colonies nine days after grafting and emerged in an incubator at $35^{\circ} \mathrm{C}$. Upon emergence, the queens' wings were clipped and individually stored for genetic analysis. Newly emerged queens were placed with 20-30 newly emerged attendant bees until insemination.

\subsection{Instrumental insemination of queens and collection of workers}

Three scutellata and three capensis queens were artificially inseminated (Laidlaw, 1978) between five and nine days after emergence. For each queen we used semen from five capensis and five scutellata drones. Semen was collected alternately from drones of the two different subspecies. Once all semen was collected in the capillary, the queen was anaesthetised with $\mathrm{CO}_{2}$ and inseminated. Even though we did not measure the exact volumes used, we took care that a similar amount of semen was used for each queen. We then introduced the queens into 5-frame scutellata colonies with scutellata workers and brood to maximise acceptance of the inseminated queens. As there are no diagnostic markers that distinguish capensis and scutellata subspecies (Franck et al., 2001), we kept the drones used for genetic analysis so that we could determine the father of the workers sampled.

As soon as queen-produced brood was about to eclose, we collected either pupae or freshly emerged workers from each colony. Thereafter we collected emerging brood at monthly intervals for three months. We collected approximately 100 workers from each of the six colonies at each sampling date. Previous findings suggest that if there is an effect of sperm competition it is apparent by the third month post insemination (DeGrandiHoffman et al., 2003). Therefore, sampling ended after the fourth month.

\subsection{Genetic analyses}

DNA was obtained from the queen (wingtips), the fathering drones and workers and pupae (23 legs) from each colony using a high salt extraction method (Aljanabi and Martinez, 1997). The fathering drones were screened with seven Apis mellifera microsatellite markers used in previous parentage studies: Am005, Am006, Am008, Am046, Am052, Am059 and Am061 (Solignac et al., 2003). For colony $\mathrm{C} 1$, one microsatellite marker was sufficient for distinguishing capensis and scutellata patrilines (Am061). For the other colonies, duplex polymerase chain reactions were required (Colonies S1 and C2: Am008/Am061, Colonies S2 and S3: Am008/Am059, Colony C3: Am046/Am061).

PCR product $(0.4 \mu \mathrm{L})$ from each multiplex reaction was added to $10 \mu \mathrm{L}$ formamide and $100 \mathrm{~nL} \mathrm{LIZ}$ DNA size standard (Applied Biosystems). Samples 
were run on a 3130xl Genetic Analyser (Applied Biosystems) with capillary length $36 \mathrm{~cm}$ and injection time of $15 \mathrm{~s}$ at $1200 \mathrm{~V}$ for $41 \mathrm{~min}$. Results were analysed using Genemapper 3.7 (Applied Biosystems) and the patriline (capensis or scutellata) of each individual was determined.

\subsection{Statistical analyses}

We calculated the proportion of workers sired by scutellata drones produced in each month by each queen. We used contingency tests on the number of workers sired by capensis and scutellata fathers to test for change in this proportion each month by each queen and to compare the total number of scutellata-patrilines produced by each queen subspecies. We further tested if colonies within subspecies show the same directional change using $\chi^{2}$ tests of heterogeneity.

\section{RESULTS}

We found a high degree of variability among the colonies in the number of workers sired by scutellata drones (Tab. I and Fig. 1). The number of scutellata-patriline individuals changed significantly over time in 3 of 6 colonies (Tab. I and Fig. 1). Sperm use within queen subspecies was variable (Tab. I and Fig. 1). There was a significant effect of queen genotype on the number of scutellata derived workers, with scutellata queens producing a significantly higher number of scutellata patriline workers than capensis queens (data pooled per queen subspecies, $\chi_{1}^{2}=$ 114.593, $P<0.001$ ) (Fig. 1).

\section{DISCUSSION}

DeGrandi-Hoffman et al. (2003) found a significant increase in the number of workers sired by scutellata drones in the second, third and fourth month after insemination and concluded that this was evidence for sperm competition. Contrary to their results we found no directional increase in the contribution of scutellata drones. If anything, our results seem to suggest that the number of scutellata-produced offspring decreases over time,
Table I. $\chi^{2}$ tests of the change in number of workers sired by scutellata drones over time (months 14 , apart from colony $\mathrm{S} 2$ which lost its queen during the fourth month before samples could be collected) per colony (S1-S3: colonies headed by scutellata queens, C1-C3: colonies headed by capensis queens). See Figure 1 for a graphical representation of the data. A significant bias towards use of sperm of a particular subspecies was detected in colonies $\mathrm{S} 3, \mathrm{C} 1$ and $\mathrm{C} 3$ (see Fig. 1 for the direction of change). To determine if colonies within subspecies show the same directional change, we performed heterogeneity tests. Heterogeneity $\chi^{2}$ were calculated by taking the absolute value of the difference of ' $\chi^{2}$ of Total' and the 'Total of $\chi^{2}$. $p$-values were calculated from the $\chi^{2}$-distribution of the $\chi^{2}$ values and degrees of freedom. Within queen genotypes there was a significant heterogeneity among colonies.

\begin{tabular}{|c|c|c|c|}
\hline \multicolumn{4}{|c|}{ Scutellata queens } \\
\hline & $\chi^{2}$ & $d f$ & $P$ \\
\hline S1 & 6.128 & 3 & 0.106 \\
\hline $\mathrm{S} 2$ & 2.969 & 2 & 0.227 \\
\hline S3 & 13.664 & 3 & 0.003 \\
\hline$\chi^{2}$ of Total & 10.535 & 3 & 0.015 \\
\hline Total of $\chi^{2}$ & 22.761 & 8 & 0.004 \\
\hline Heterogeneity & 12.226 & 5 & 0.032 \\
\hline \multicolumn{4}{|c|}{ Capensis queens } \\
\hline & $\chi^{2}$ & $\overline{d f}$ & $P$ \\
\hline $\mathrm{C} 1$ & 18.992 & 3 & $<0.001$ \\
\hline $\mathrm{C} 2$ & 1.348 & 3 & 0.718 \\
\hline C3 & 15.323 & 3 & 0.002 \\
\hline$\chi^{2}$ of Total & 20.749 & 3 & $<0.001$ \\
\hline Total of $\chi^{2}$ & 35.663 & 9 & $<0.001$ \\
\hline Heterogeneity & 14.914 & 6 & 0.021 \\
\hline
\end{tabular}

especially in capensis queens (Fig. 1). Although the number of spermatozoa produced by capensis $(8.9 \pm 1.1$ million, Buys, 1990) and AHB (9.2 \pm 1.8 million, Rinderer et al., 1985) drones are similar (no data are available for scutellata in South Africa), the variance among drones is enormous within subspecies and even breeder lines (Koeniger et al., 2005). Our colonies varied significantly in the number of scutellata workers produced over time, and this may possibly be explained by differences in spermatozoa numbers among drones. We note however, that the number of spermatozoa produced by drones is not 


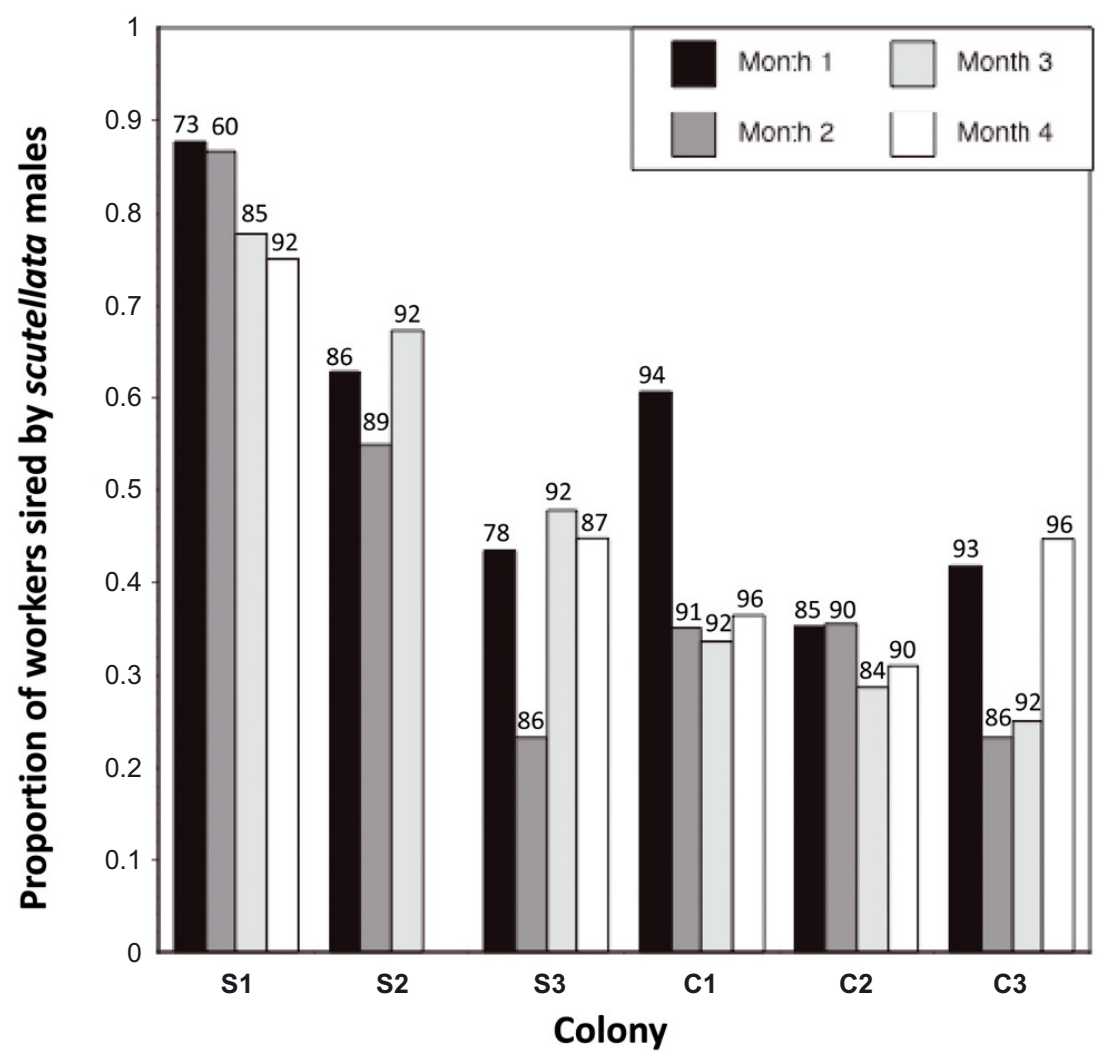

Figure 1. Proportion of individuals sired by scutellata drones produced in each month by scutellata (S1S3) and capensis queens (C1-C3). A significant bias towards use of sperm of a particular genotype was detected in colonies S3, C1 and C3 (see Tab. I). Numbers above bars represent the total number of bees successfully genotyped for that sampling date. When pooled across queen genotype scutellata queens produced a significantly higher proportion of scutellata patriline workers than capensis queens $\left(\chi_{1}^{2}=114.593\right.$, $P<0.001)$.

directly correlated with paternity frequency as spermatozoa numbers are significantly lower in AHB drones compared with European drones (Rinderer et al., 1985). Nonetheless in the study by DeGrandi-Hoffman et al. (2003) AHB drones sired disproportionally more workers than European drones.

Interestingly, our results also show that capensis queens produced more capensis patriline offspring, while scutellata queens produced more scutellata patriline offspring despite the presence of sperm of both subspecies in the queens' spermatheca (Fig. 1). Such an effect of queen subspecies was absent in the study of DeGrandi-Hoffman et al. (2003). Our results suggest that scutellata sperm may be disadvantaged in capensis queens. A similar 'same subspecies advantage' has been reported in mating swarms of mixed honeybee subspecies where queens produced more offspring sired by drones of their own subspecies (Koeniger et al., 1989). The mechanisms that lead to assortative paternity are unknown, but in our study we can exclude any effect of female mate choice (Baer, 2005). Assortative paternity in our study could have arisen either via cryptic female choice prior to fertilization, or the preferential rearing of pure subspecies' offspring. The latter would lead to an increase over time of workers sired by drones of the same subspecies as the queen, consistent with our results when the data are pooled 
across queen subspecies. However, given the small colony-level sample size and the significant variation among colonies within the same subspecies, we recommend that the conclusion that offspring of each subspecies are overrepresented in hybrid colonies headed by queens of the same subspecies be viewed with caution. A more thorough study is required. Should it be confirmed however, then this would be a significant factor in the capensisscutellata hybrid zone dynamics and in the stability of the hybrid zone (Beekman et al., 2008).

\section{ACKNOWLEDGEMENTS}

We thank Christian Fransman for his help in the field. Marcus McHale, Julie Lim and Rute Brito assisted with genetic analysis. Thank you to three anonymous reviewers whose comments improved the manuscript. B.P.O. and M.B. are supported by the Australian Research Council. M.B. further acknowledges support from the University of Sydney. T.C.W. is supported by the National Research foundation.

Utilisation du sperme chez les abeilles (Apis mellifera scutellata and $A$. m. capensis) en Afrique du Sud.

Apis mellifera scutellata / Apis mellifera capensis / compétition spermatique / africanisation/ zone hybride

Zusammenfassung - Spermiennutzung bei Honigbienen (Apis mellifera scutellata und A. m. capensis) in Südafrika. In Südafrika kommen zwei verschiedene Unterarten der Honigbiene vor: die Kaphonigbiene, Apis mellifera capensis, und die afrikanische Honigbiene, A. m. scutellata. Die beiden Unterarten sind durch eine Hybridisierungszone getrennt, in welcher sie sich miteinander kreuzen. Die Kaphonigbiene ist als sozialer Parasit der afrikanischen Honigbiene bekannt und hat massive Völkerverluste versursacht, als sie in Gebiete eingeführt wurde, wo normalerweise nur A. $m$. scutellata vorkommt. Interessanterweise scheint $A$. m. capensis trotz ihrer Fähigkeit zum Parasitentum nicht in der Lage zu sein, die Hybridisierungszone ohne Hilfe zu durchqueren. Auch A. m. scutellata hat besondere Eigenschaften. Nach ihrer Einfuhr nach Brasilien im Jahr 1956 hat sie im Laufe von 20 Jahren alle anderen dort vorkommenden Unterarten der Honigbiene durch Konkurrenz verdrängt. Ihr Erfolgs- geheimnis scheint dabei ihre besonders hohe Vermehrungsrate zu sein. In einer kürzlich veröffentlichten Studie wurde vorgeschlagen, dass A. m. scutellata auch durch Spermienkonkurrenz in der Lage ist, andere Unterarten auf den amerikanischen Doppelkontinent zu verdrängen. Hier haben wir untersucht, ob es in Königinnen, die sowohl mit Sperma von $A$. m. capensis als auch von A. m. scutellata besamt wurden, zu Spermienkonkurrenz kommt. Wir haben sowohl Königinnen von A. m. capensis als auch von A. $m$. scutellata mit Sperma, das von einer gleichen Anzahl Drohnen beider Unterarten abgenommen wurde, besamt. Durch monatliches Absammeln und Genotypisieren von ArbeiterinnenNachkommen haben wir den relativen Anteil der A. m. scutellata Drohnen an den erzeugten Arbeiterinnen bestimmt. Wir haben keinen höheren Anteil von Arbeiterinnen mit A. m. scutellata Vätern gefunden. Unsere Ergebnisse scheinen höchstens anzudeuten, dass Königinnen das Sperma von Männchen ihrer eigenen Unterart bevorzugen. $\mathrm{Ob}$ dieser Effekt wirklich besteht, muss in einer ausführlicheren Untersuchung geklärt werden.

Apis mellifera scutellata / Apis mellifera capensis / Spermienkonkurrenz / Afrikanisierung / Hybridisierungszone

\section{REFERENCES}

Aljanabi S.M., Martinez, I. (1997) Universal and rapid salt-extraction of high quality genomic DNA for PCR-based techniques, Nucleic Acids Res. 25, 4692-4693.

Allsopp M. (1992) The capensis calamity, S. Afr. Bee J. 64, 52-57.

Anderson R.H. (1980) Cape honey-bee sanctuaries, S. Afr. Bee J. 52, 5-9.

Baer B. (2005) Sexual selection in Apis bees, Apidologie 36, 187-200.

Beekman M., Allsopp M.H., Wossler T.C., Oldroyd B.P. (2008) Factors affecting the dynamics of the honey bee (Apis mellifera) hybrid zone in South Africa, Heredity 100, 13-18.

Buys B. (1990) Features of basic reproduction in drones and queens of the Cape honeybee Apis mellifera capensis, in: Anderson R.H., Buys B. (Eds.), Proceedings of the International Beekeepers' Symposium: Bees and beekeeping in Southern Africa, Posa \& WPBA, Cape Town, pp. 106-109.

DeGrandi-Hoffman G., Tarpy D.R., Schneider S.S. (2003) Patriline composition of worker populations in honeybee (Apis mellifera) colonies headed by queens inseminated with semen from African and European drones, Apidologie 34, 111-120.

Franck P., Garnery L., Loiseau A., Oldroyd B.P., Hepburn H.R., Solignac M., Cornuet J.-M. (2001) 
Genetic diversity of the honeybee in Africa: microsatellite and mitochondrial data, Heredity 86, 420-430.

Hepburn H.R., Crewe, R.M. (1991) Portrait of the Cape honeybee, Apis mellifera capensis, Apidologie 22, 567-580.

Hepburn H.R., Radloff S.E. (1998) Honeybees of Africa, Springer, Berlin.

Koeniger G., Koeniger N., Pechhacker H., Ruttner F., Berg S. (1989) Assortative mating in a mixed population of European honeybees, Apis mellifera ligustica and Apis mellifera carnica, Insectes Soc. $36,129-138$.

Koeniger G., Koeniger N., Tingek S., Phiancharoen M. (2005) Variance in spermatozoa number among Apis dorsata drones and among Apis mellifera drones, Apidologie 36, 279-284.

Laidlaw H.H. (1978) Instrumental Insemination of Honey Bee Queens, Dadant \& Sons, Inc., Hamilton, Illinois.

Martin S.J., Wossler T.C., Kryger P. (2002) Usurpation of African Apis mellifera scutellata colonies by parasitic Apis mellifera capensis workers, Apidologie 33, 215-232.

Onions G.W. (1912) South African "Fertile" worker bees, S. Afr. Bee J. 1, 720-728.

Rinderer T.E., Collins A.M., Pesante D., Daniel R., Lancaster V., Baxter J. (1985) A comparison of Africanized and European drones: eights, mucuc gland and seminal vesicle weights, and counts of spermatozoa, Apidologie 16, 407-412.

Solignac M., Vautrin D., Loiseau A., Mougel F., Baudry E., Estoup A., Garnery L., Haberl M., Cornuet J.-M. (2003) Five hundred and fifty microsatellite markers for the study of the honeybee (Apis mellifera L.) genome, Mol. Ecol. Notes 3, 307-311.

Spivak M., Breed M.D., Fletcher D.J.C. (1991) The African Honey Bee, Westview Press, Boulder, Colorado.

Verma S., Ruttner, F. (1983) Cytological analysis of the thelytokous parthenogenesis in the Cape honeybee (Apis mellifera capensis Escholtz), Apidologie 14, 41-57. 